\title{
Chronic left ventricular pseudo-aneurysm after posterior myocardial infarction
}

\author{
Liam S Hirt \\ Department of Cardiology, Royal United Hospitals, Bath, UK
}

Correspondence to Dr Liam S Hirt, liam.hir @googlemail.com

\section{DESCRIPTION}

A 69-year-old man was seen among outpatients after an episode of chest pain. He was pain-free and haemodynamically stable. His electrocardiogram was normal, but a pan-systolic murmur was noted on examination. He was referred for outpatient exercise treadmill testing and transthoracic echocardiography.

The echocardiogram demonstrated an akinetic basal posterior wall of the left ventricle that had thinned to the point of rupture (figure 1). Adjacent was a large pseudo-aneurysm measuring $4.5 \times 7.5 \mathrm{~cm}^{2}$. Flow across the posterior wall was demonstrated with colour and pulse wave Doppler (figure 2). Subsequent coronary angiography revealed three vessel coronary artery disease with a severe stenosis in the mid-circumflex artery.

Rupture of the left ventricular free wall is very uncommon and is almost universally catastrophic. In rare instances the rupture is contained and a pseudo-aneurysm develops. Pseudo-aneurysms usually occur after myocardial infarction, but can occur after surgery or infection.

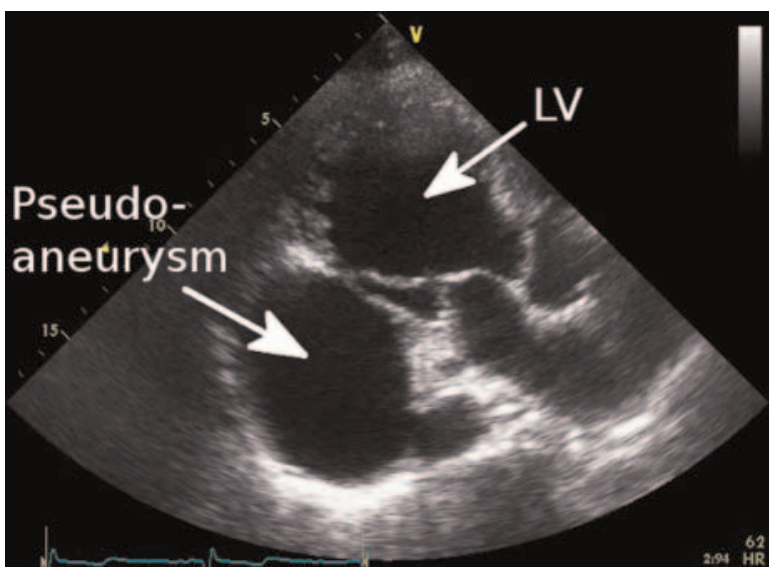

Figure 1 Transthoracic echocardiogram demonstrating a large pseudo-aneurysm adjacent to the posterior wall.

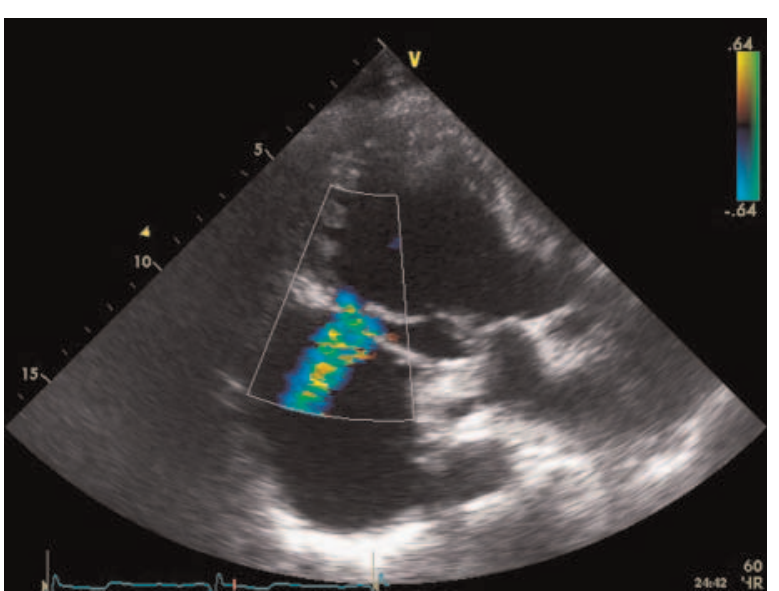

Figure 2 Transthoracic echocardiogram with colour Doppler demonstrating flow across the posterior wall into the pseudo-aneurysm.

They develop when a rupture is contained by pericardial adhesions. Pseudo-aneurysms are most commonly associated with the inferior or posterior wall, have a narrow neck communicating with the left ventricle and are prone to expansion and rupture. ${ }^{1}$ Left venticular rupture and pseudo-aneurysm formation after myocardial infarction can be reduced by early restoration of blood flow. ${ }^{2}$ and early use of $\beta$-blockers and ACE inhibitors. Once pseudo-aneurysms have formed they must be corrected surgically before rupture.

Competing interests None.

Patient consent Obtained.

\section{REFERENCES}

1. Frances C, Romero A, Grady D. Left ventricular pseudoaneurysm. J Am Coll Cardiol 1998;32:557-61.

2. Yip HK, Wu CJ, Chang HW, et al. Cardiac rupture complicating acute myocardial infarction in the direct percutaneous coronary intervention reperfusion era. Chest 2003;124:565-71. 


\section{BMJ Case Reports}

This pdf has been created automatically from the final edited text and images.

Copyright 2012 BMJ Publishing Group. All rights reserved. For permission to reuse any of this content visit http://group.bmj.com/group/rights-licensing/permissions.

BMJ Case Report Fellows may re-use this article for personal use and teaching without any further permission.

Please cite this article as follows (you will need to access the article online to obtain the date of publication)

Hirt LS. Chronic left ventricular pseudo-aneurysm after posterior myocardial infarction. BMJ Case Reports 2012;10.1136/bcr-2012-006533, Published XXX

Become a Fellow of BMJ Case Reports today and you can:

- Submit as many cases as you like

- Enjoy fast sympathetic peer review and rapid publication of accepted articles

- Access all the published articles

- Re-use any of the published material for personal use and teaching without further permission

For information on Institutional Fellowships contact consortiasales@bmjgroup.com

Visit casereports.bmj.com for more articles like this and to become a Fellow 